\title{
Factors Related to Stunted in East Java Province in 2019: An Ecological Analysis
}

\author{
Azizah Andzar Ridwanah ${ }^{1}$, Hario Megatsari², Agung Dwi Laksono ${ }^{3}$, Mursyidul Ibad $^{4}$ \\ ${ }^{1}$ Officer, Health Office of East Java Province, Surabaya, Indonesia, ${ }^{2}$ Lecturer, Faculty of Public Health, \\ Universitas Airlangga, Surabaya, Indonesia, ${ }^{3}$ Researcher, National Institute of Health Research and Development \\ the Indonesia Ministry of Health, Jakarta, Indonesia, ${ }^{4}$ Lecturer, Faculty of Health, Nadlatul Ulama University, \\ Surabaya, Indonesia
}

\begin{abstract}
East Java Province has a high prevalence of stunted. The study aimed to analyze the factors associated with stunted in East Java Province. The study was conducted using secondary data sourced from the 2019 East Java Province Health Profile report. The study was designed with an ecological analysis approach. All 38 regencies/cities in East Java Province were analyzed. Apart from the prevalence of stunted toddlers as the dependent variable, 4 other variables were analyzed as independent variables, namely the coverage of toddler health services, Universal Child Immunization (UCI) village coverage, coverage of families accessing healthy latrines, and percentage of samples of drinking water facilities that meet the requirements. The results showed that the trend of regencies/cities with low coverage of toddler health services has a high prevalence of stunted toddlers. There was a tendency for regencies/cities that have a higher level of immunization coverage which tends to have a lower percentage of stunted toddlers. Meanwhile, the trend of regencies/cities that have better coverage of families accessing healthy latrines has a lower prevalence of stunted toddlers. Finally, regencies/cities with a high percentage of babies receiving exclusive breastfeeding have the lowest prevalence of babies receiving exclusive breastfeeding. It could be concluded that there is a tendency for a negative relationship between the independent variables analyzed and the prevalence of stunted toddlers. The higher the coverage on the independent variable, the lower the tendency for the coverage percentage to be stunted in East Java Province.
\end{abstract}

Keywords: Ecological analysis, secondary data,stunted, community nutrition.

\section{Introduction}

Stunted in toddlers is a nutritional problem that is a world issue, including in Indonesia. Stunted is a condition in which toddlers have less length or height compared to age. This condition is measured by a length or height that is more than minus two standard deviations from the WHO median growth standard for children ${ }^{1}$.

Based on the 2019 Health Profile of East Java Province report, East Java Province still has a fairly high

\footnotetext{
Corresponding Author:

Hario Megatsari

Lecturer, Faculty of Public Health, Universitas

Airlangga, Surabaya, Indonesia

e-mail: hario.megatsari@fkm.unair.ac.id
}

prevalence of stunted. In 2016 the prevalence of stunted was $26.10 \%$, while in 2017 it increased to $26.70 \%$, and in 2018 it decreased to $22 \%^{2}$. Meanwhile, based on the 2018 Basic Health Survey, the record of the prevalence of stuntedness in East Java Province is even higher, higher than the national average. The prevalence of stunted toddler in East Java Province is $19.9 \%$, while the national rate is $19.3 \%$. The prevalence of severely stunted in East Java Province is $12.9 \%$, while the national one is $11.5 \%{ }^{3}$.

Stunted is known to be one of the main causes of morbidity in children under five years of age $e^{4,5}$. Children who are stunted can have a higher risk for chronic diseases such as obesity and hypertension ${ }^{6}$. The final impact, stunted can reduce the quality of human resources which can result in decreased welfare of 
society. Stunted can lead to long-term effects including cognitive impairment and physical development, lower performance, lower per capita income, increased risk of poverty, increased risk of pregnancy disorders and asphyxia during childbirth, as well as increased risk of degenerative diseases such as obesity, diabetes mellitus, heart disease, stroke, hypertension, and cancer ${ }^{7,8}$.

HL Blum stated that the factors that affect health are divided into four elements, including environment, heredity, lifestyle, and health services ${ }^{5}$. Stunted as one of the national health problems that are now a concern requires an in-depth analysis of the causative factors in prevention and overcoming efforts. When viewed using the Blum theory, several variables that can be analyzed include the coverage of under-five health services and the Universal Child Immunization (UCI) village coverage which is one of the elements of activity of the determinants of health services. Besides, there is a variable percentage of babies who are exclusively breastfed as one of the variables of parenting/behavior that can be analyzed. The coverage of households that have access to healthy latrines is the chosen variable to analyze environmental factors against stunted. Based on the background description, this study aims to analyze the factors related to stunted in East Java Province in 2019.

\section{Materials and Method}

The study was designed using an ecological analysis approach. Ecological studies focus on comparisons between groups, not individuals. The data analyzed is aggregate data at a certain group or level, which in this study is the regency/city level. The variables in an ecological analysis can be aggregate measurements, environmental measurements, or global measurements ${ }^{9,10}$.
The study was conducted using secondary data from the 2019 East Java Provincial Health Profile report. A total of 38 regencies/cities in East Java were involved in this analysis. The dependent variable in this study was the prevalence of stunted toddlers. There are 4 independent variables analyzed, namely the coverage of under-five health services, the coverage of UCI villages, the coverage of households that access healthy latrines, the percentage of infants receiving exclusive breastfeeding. All variables are categorized into 3 parts of the same size. Data were analyzed by univariate and bivariate. Bivariate analysis was performed using crosstabulations. The entire analysis process utilizes SPSS 21 software.

\section{Results and Discussion}

Table 1 shows the descriptive statistics of the variables in the ecological analysis of stunted toddlers in East Java. Table 1 shows the distribution of stunted as the dependent variable with positive values in the low category and negative in the high category. In general, the target of stunted performance is to reduce its prevalence in the community. The 5 independent variables include the percentage of infants receiving exclusive breastfeeding, the coverage of under-five health services, UCI village coverage, the percentage of families accessing healthy latrines. The sample was 38 regencies/cities in East Java Province. Based on the table, it is found that the figure is more than $100 \%$ due to regencies/cities reporting coverage that exceeds the target set at the beginning of the evaluation year. The lowest prevalence of stunted toddler was in Tulungagung Regency at $5.3 \%$ and the highest was in Batu City at $25.4 \%$. The average prevalence of stunted toddlers from 38 regencies/cities was $13.72 \%$.

Table 1. Descriptive Statistics of Stunted Toddlers in East Java Province in 2019

\begin{tabular}{|l|c|c|c|c|c|}
\hline & $\begin{array}{c}\text { Prevalence of } \\
\text { Stunted Toddler }\end{array}$ & $\begin{array}{c}\text { Toddler } \\
\text { Health Service } \\
\text { Coverage }\end{array}$ & $\begin{array}{c}\text { UCI Village } \\
\text { Coverage }\end{array}$ & $\begin{array}{c}\text { Percentage of Households } \\
\text { that Have Access to } \\
\text { Healthy Latrines }\end{array}$ & $\begin{array}{c}\text { Exclusive } \\
\text { Breastfeeding } \\
\text { Coverage }\end{array}$ \\
\hline $\mathrm{N}$ & 38 & 38 & 38 & 38 & 38 \\
\hline Mean & 13.7211 & 89.9079 & 90.4395 & 92.8474 & 78.0316 \\
\hline Median & 13.0000 & 91.2000 & 92.0500 & 96.2000 & 78.8000 \\
\hline Mode & $15.30^{\mathrm{a}}$ & $90.90^{\mathrm{a}}$ & 100.00 & 100.00 & $78.70^{\mathrm{a}}$ \\
\hline Std. Deviation & 4.99492 & 7.40388 & 9.81258 & 9.14185 & 9.54953 \\
\hline Variance & 24.949 & 54.818 & 96.287 & 83.573 & 91.194 \\
\hline
\end{tabular}




\begin{tabular}{|l|c|c|c|c|c|}
\hline & $\begin{array}{c}\text { Prevalence of } \\
\text { Stunted Toddler }\end{array}$ & $\begin{array}{c}\text { Toddler } \\
\text { Health Service } \\
\text { Coverage }\end{array}$ & $\begin{array}{c}\text { UCI Village } \\
\text { Coverage }\end{array}$ & $\begin{array}{c}\text { Percentage of Households } \\
\text { that Have Access to } \\
\text { Healthy Latrines }\end{array}$ & $\begin{array}{c}\text { Exclusive } \\
\text { Breastfeeding } \\
\text { Coverage }\end{array}$ \\
\hline Range & 20.10 & 38.10 & 48.80 & 34.10 & 49.50 \\
\hline Minimum & 5.30 & 63.00 & 51.20 & 66.20 & 46.90 \\
\hline Maximum & 25.40 & 101.10 & 100.00 & 100.30 & 96.40 \\
\hline
\end{tabular}

Source: The 2019 Health Profile of East Java Province

Table 2. Cross-tabulation between Stunted Toddler Prevalence and Health Service Coverage for Toddlers in East Java Province, 2019

\begin{tabular}{|c|c|c|c|c|c|c|}
\hline \multirow{3}{*}{$\begin{array}{l}\text { Toddler Health Service } \\
\text { Coverage }\end{array}$} & \multicolumn{6}{|c|}{ Stunted Toddler } \\
\hline & \multicolumn{2}{|c|}{ Low (5.30-11.00\%) } & \multicolumn{2}{|c|}{ Middle (11.10\%-16.10\%) } & \multicolumn{2}{|c|}{ High (16.11\%-25.40\%) } \\
\hline & $\mathbf{N}$ & $\%$ & $\mathbf{N}$ & $\%$ & $\mathbf{n}$ & $\%$ \\
\hline Low $(63.00 \%-89.90 \%)$ & 3 & 23.1 & 3 & 23.1 & 6 & 50.0 \\
\hline Middle (89.91\%-92.30\%) & 8 & 61.5 & 8 & 61.5 & 5 & 41.7 \\
\hline High (92.31\%-101.10\%) & 2 & 15.4 & 2 & 15.4 & 1 & 8.3 \\
\hline Total & 13 & 100 & 13 & 100 & 12 & 100 \\
\hline
\end{tabular}

Source: The 2019 Health Profile of East Java Province

Table 2 shows the cross-tabulation between the prevalence of stunted toddlers and the coverage of toddler health services. The analysis showed that the trend of regencies/cities with a high prevalence of stunted toddler had low coverage of health services for children under five. The trend shows that the coverage of toddler health services contributes to reducing the percentage of stunted toddlers. Information in Table 2 shows that regencies/cities with low coverage of health services for children under five tend to have higher rates of stuntedness. This is in line with previous research which states that there is a relationship between the higher the quality of health services the better impact on child growth and stunted ${ }^{11}$. The inability of families to reach health services due to lack of knowledge, financial capacity, or other causes can affect the nutritional status of children. Health services for children can be associated with changes in nutritional status that lead to stunted ${ }^{1,6}$.

Table 3. Cross-tabulation between Stunted Toddler Prevalence and Universal Child Immunization (UCI) Village Coverage in East Java Province, 2019

\begin{tabular}{|c|c|c|c|c|c|c|}
\hline \multirow{3}{*}{ Village Coverage of UCI } & \multicolumn{6}{|c|}{ Stunted Toddler } \\
\hline & \multicolumn{2}{|c|}{ Low (5.30-11.00\%) } & \multicolumn{2}{|c|}{ Middle (11.10\%-16.10\%) } & \multicolumn{2}{|c|}{ High (16.11\%-25.40\%) } \\
\hline & $\mathbf{N}$ & $\%$ & $\mathbf{N}$ & $\%$ & $\mathbf{N}$ & $\%$ \\
\hline Low $(51.20 \%-89.00 \%)$ & 3 & 23.1 & 3 & 23.1 & 7 & 58.3 \\
\hline Middle (89.01\%-96.90\%) & 3 & 23.1 & 6 & 46.2 & 4 & 33.3 \\
\hline High $(96.90 \%-100.00 \%)$ & 7 & 53.8 & 4 & 30.8 & 1 & 8.3 \\
\hline Total & 13 & 100 & 13 & 100 & 12 & 100 \\
\hline
\end{tabular}

Source: The 2019 Health Profile of East Java Province

Table 3 is the result of cross-tabulation between stunted toddler prevalence and UCI village coverage in East Java Province. Table 3 shows the tendency for regencies/cities with the highest percentage of stunted toddlers to regencies/cities with high UCI Village coverage, namely $53.8 \%$. It can be seen that there is a 
tendency that regencies/cities that have higher levels of immunization coverage tend to have a lower percentage of stunted. Previous studies reported that cases of stunted toddler and wasting were found to be more in children with incomplete immunization status ${ }^{12,13}$ i.e., BCG; measles; polio 3; and Diphtheria, Tetanus toxoids, and Pertussis, i.e., DTP3. Apart from having an impact on the nutritional status of children under five, immunization is needed because it is an effort to reduce child morbidity and mortality ${ }^{14}$.

Table 4. Cross-tabulation between Stunted Toddler Prevalence and Coverage of Household Accessing Healthy Latrines in East Java Province, 2019

\begin{tabular}{|c|c|c|c|c|c|c|}
\hline \multirow{3}{*}{$\begin{array}{l}\text { Household Coverage that } \\
\text { Accesses Healthy Latrines }\end{array}$} & \multicolumn{6}{|c|}{ Stunted Toddler } \\
\hline & \multicolumn{2}{|c|}{ Low (5.30-11.00\%) } & \multicolumn{2}{|c|}{ Middle (11.10\%-16.10\%) } & \multicolumn{2}{|c|}{ High $(16.11 \%-25.40 \%)$} \\
\hline & $\mathbf{N}$ & $\%$ & $\mathbf{n}$ & $\%$ & $\mathbf{N}$ & $\%$ \\
\hline Low $(66.20 \%-92.80 \%)$ & 1 & 7.7 & 5 & 38.5 & 3 & 23.7 \\
\hline Middle (92.81\%-98.20\%) & 3 & 23.1 & 4 & 30.8 & 4 & 33.3 \\
\hline High $(98.20 \%-100.30 \%)$ & 9 & 69.2 & 4 & 30.8 & 5 & 41.7 \\
\hline Total & 13 & 100 & 13 & 100 & 12 & 100 \\
\hline
\end{tabular}

Source: The 2019 Health Profile of East Java Province

Table 4 shows the cross-tabulation between stunted toddler prevalence and coverage of households accessing healthy latrines in East Java Province. The apparent trend is that regencies/cities with a low percentage of stunted toddlers are found in regencies/cities with high coverage of households accessing healthy latrines. The information presented in Table 4 shows the trend of regencies/cities with better coverage of families accessing healthy latrines having a lower percentage of stunted. This shows that access to sanitation has an impact on the percentage of stunted in the community. This tendency is in line with the results of previous studies which state that there is a relationship between latrine use and being stunted in children ${ }^{7}$. In previous studies, hygiene and sanitation have been shown to have a linear relationship with growth in children ${ }^{15}$. Poor sanitation increases the risk of infectious diseases and impaired absorption of nutrients. Research states that health problems due to poor sanitation are associated with growth problems that can result in stuntedness ${ }^{16,17}$ broader efforts are needed that reach beyond the nutrition sector to tackle the underlying determinants of undernutrition. There is growing interest in how water, sanitation and hygiene (WASH).

Table 5. Cross-tabulation between Stunted Toddler Prevalence and Percentage of Babies Receiving Exclusive Breastfeeding in East Java Province, 2019

\begin{tabular}{|c|c|c|c|c|c|c|}
\hline \multirow{3}{*}{$\begin{array}{l}\text { Percentage of Babies } \\
\text { Receiving Exclusive } \\
\text { Breastfeeding }\end{array}$} & \multicolumn{6}{|c|}{ Stunted Toddler } \\
\hline & \multicolumn{2}{|c|}{ Low (5.30-11.00\%) } & \multicolumn{2}{|c|}{ Middle (11.10\%-16.10\%) } & \multicolumn{2}{|c|}{ High (16.11\%-25.40\%) } \\
\hline & $\mathbf{n}$ & $\%$ & $\mathbf{n}$ & $\%$ & $\mathbf{n}$ & $\%$ \\
\hline Low (46.90\%-75.90\%) & 5 & 38.5 & 5 & 38.5 & 3 & 25.0 \\
\hline Middle (75.91\%-81.40\%) & 3 & 23.1 & 4 & 30.8 & 7 & 58.3 \\
\hline High ( $81.41 \%-96.40 \%)$ & 5 & 38.5 & 4 & 30.8 & 2 & 16.7 \\
\hline Total & 13 & 100 & 13 & 100 & 12 & 100 \\
\hline
\end{tabular}

Source: The 2019 Health Profile of East Java Province 
Table 5 is a cross-tabulation between stunted toddler prevalence and coverage of babies receiving exclusive breastfeeding in East Java Province. The cross-tabulation results show that the prevalence of high-category stunted toddlers is most dominant in city districts that have coverage of middle-category ASI, while regencies/cities with a high percentage of babies receiving exclusive breastfeeding have the lowest stunted toddler prevalence. In line with this trend, several previous studies have also informed that one of the factors that influence the incidence of stunted is exclusive breastfeeding ${ }^{18}$. Stunted toddlers are more common in babies who are not exclusively breastfed. Thus, exclusive breastfeeding is highly recommended ${ }^{18,19}$.

This research, which was conducted using the ecological analysis approach, has limitations in its use as a policy basis because the data used is aggregate data at the provincial level. Further study is needed at the individual level to obtain more accurate information in choosing intervention policy.

\section{Conclusions}

Based on the results of the study, it could be concluded that the coverage of toddler health services, UCI village coverage, coverage of households accessing healthy latrines, and coverage of infants receiving exclusive breastfeeding were factors related to the prevalence of stunted toddlers in East Java Province in 2019.

Acknowledgments: The author would like to thank the East Java Provincial Health Office for providing the report which was the source of the data in this study.

\section{Source of Funding: Self-funding}

Ethical Clearance: The study was conducted by utilizing secondary data from published reports. For this reason, ethical clearance is not required in the implementation of this study.

\section{Conflicting Interests: Nil}

\section{References}

1. Kusrini I, Laksono ADAD. Regional disparities of stunted toddler in indonesia. Indian J Forensic Med Toxicol. 2020;14(3):1685-91.

2. Health Office of East Java Province. The 2018 Health Profile of East Java Province. 2019.

3. National Institute of Health Research and
Development of The Indonesia Ministry of Health. The 2018 Indonesia Basic Health Survey (Riskesdas): National Report [Internet]. Jakarta; 2019. Available from: http://labmandat. litbang.depkes.go.id/images/download/laporan/ RKD/2018/Laporan\%7B\%5C_\%7DNasional\%7B \%5C_\%7DRKD2018\%7B\%5C_\%7DFINAL.pdf

4. Laksono AD, Ibad M, Mursita A, Kusrini I, Wulandari RD. Characteristics of mother as predictors of stunting in toddler. Pakistan J Nutr. 2019;18(12):1101-6.

5. Yoto M, Hadi MI, Pratita I, Syahriyatul M, Maghfiroh, Multazam AZ, et al. Social Determinants of Stunting Countermeasures: Participatory Action Research in Healthy Villages Empowered by Stunting Countermeasures (Determinan Sosial Penanggulangan Stunting: Riset Aksi Partisipatif Desa Sehat Berdaya Fokus Penanggulangan Stunting). Sumarmi S, editor. Surabaya: Health Advocacy; 2020. 1-280 p.

6. Rahayu LS, Safitri, Debby Endayani IY. Child care practice as a risk factor of changes in nutritional status from normal to stunting in under five children. J Gizi dan Diet Indones (Indonesian J Nutr Diet. 2017;5(2):77.

7. Badriyah L, Syafiq A. The Association Between Sanitation, Hygiene, and Stunting in Children Under Two-Years (An Analysis of Indonesia's Basic Health Research, 2013). Makara J Heal Res. 2017;21(2).

8. Laksono AD, Megatsari $H$. Determinants of Stunted Toddler in East Java: Analysis of the 2017 Nutrition Status Monitoring Data. Amerta Nutr. 2020;4(2):109-15.

9. Morgenstern H. Ecologic Studies in Epidemiology: Concepts, Principles, and Method. Annu Rev Public Health. 1995;16:61-81.

10. Laksono AD, Kusrini I. Ecological Analysis of Stunted Toddler in Indonesia. Indian J Forensic Med Toxicol. 2020;14(3):1685-91.

11. Titaley CR, Ariawan I, Hapsari D, Muasyaroh A, Dibley MJ. Determinants of the Stunting of Children Under Two Years Old in Indonesia: A Multilevel Analysis of the 2013 Indonesia Basic Health Survey. Nutrients. 2019 May;11(5):1106.

12. Solis-Soto T, Paudel D, Nicoli F. Relationship between vaccination and nutritional status in children: Analysis of recent demographic and health 
surveys. Demogr Res. 2020;42(January):1-14.

13. Budiastutik I, Rahfiludin MZ. Risk Factors of Child Stunting in Developing Countries. J Amerta Nutr. 2019;122-6.

14. Fajariyah RN, Hidajah AC. Correlation Between Immunization Status and Mother'S Height, and Stunting in Children 2-5 Years in Indonesia. J Berk Epidemiol. 2020;8(1):89.

15. Rah JH, Sukotjo S, Badgaiyan N, Cronin AA, Torlesse H. Improved sanitation is associated with reduced child stunting amongst Indonesian children under 3 years of age. Matern Child Nutr. 2020;16(S2):Article number e12741.

16. Cumming O, Cairncross S. Can water, sanitation and hygiene help eliminate stunting? Current evidence and policy implications. Matern Child Nutr. 2016;12:91-105.

17. Apriluana G, Fikawati S. Analysis of Risk Factors of Stunting Among Children 0-59 Months in Developing Countries and Southeast Asia. Media Penelit dan Pengemb Kesehat. 2018;28(4).

18. Rusmil VK, Prahastuti TO, Erlangga Luftimas D, Hafsah T. Exclusive and Non-Exclusive Breastfeeding among Stunted and Normal 6-9 Month-Old-Children in Jatinangor Subdistrict, Indonesia. Althea Med J. 2019;6(1):35-41.

19. Wulandari RD, Laksono AD. Does the Place of Residence Affect the Achievement of Exclusive Breastfeeding? A Study in Eastern Indonesia. Syst Rev Pharm. 2020;11(9):872-6. 